\title{
Utilization and cost benefit analyses of Oreochromis niloticus fed fermented cassava, Manihot esculentus leaf meal supplemented diets
}

\begin{abstract}
The high cost of feeding is detrimental to the growth, sustainability and profitability of aquaculture; hence alternative ingredients are been sourced to reduced this cost. $6 \mathrm{~kg}$ of Cassava leaves were collected fresh from cassava farm; washed and divide into two-equal halves. One half was blanched while other fermented then each divided into equal halves. One part sun-dried and other air-dried then proximate composition and hydrocyanide were analysed. Fermented and Feed-growth response experiment was conducted in which Juvenile Oreochromis niloticus were fed diets where fermented and sun-dried cassava leaf meal (FSCLM) was used to substitute for soybean meal at $0 \%, 25 \%, 50 \%, 75 \%$ and $100 \%$ levels to formulate $35 \%$ isoproteic diets for twelve weeks. The results of the experiment showed reduced hydrocyanide content and increased crude protein in fermented \& sundried followed by fermented and air-dried cassava leaf meal and these were significantly different $(p<0.05)$. The feed-growth response results indicated that 100\% FSCLM diet has the highest growth performance and nutrient utilization while 50\% CLM inclusion has the lowest. The mean weight gain ranged between $5.67-18.83 \mathrm{~g} /$ fish, feed conversion ratio was between 1.455-1.723, protein efficiency ratio was 1.099-1.314 and specific growth rate between $1.75-2.16 \%$ /day. The highest benefit cost ratio of 1.27 was recorded in fingerlings fed $100 \%$ cassava leaves meal inclusion diet and lowest of 0.72 from those fed $50 \%$ cassava leaves meal inclusion diet.
\end{abstract}

Keywords: Oreochromis niloticus, fermented \& sun-dried cassava leaf meal, processing, feed utilization, cost benefit analyses
Volume 7 Issue 4 - 2018

\author{
Sogbesan OA,' Bashir SY' \\ 'Department of Fisheries, Modibbo Adama University of \\ Technology, Nigeria \\ ${ }^{2}$ Department of Zoology, Modibbo Adama University of \\ Technology, Nigeria
}

Correspondence: Sogbesan OA, Department of Fisheries, Modibbo Adama University of Technology, Nigeria, Email sokayfish@mautech.edu.ng

Received: May 06, 2018 | Published: July 19, 2018

\section{Introduction}

Food Fish is the only important aquatic animal food source that is captured the wild rather and can also be farmed. However, capture fisheries have not been able to meet up with the growing demand while the wild is approaching full exploitation. ${ }^{1,2}$ The mandate to increase meets the ever-increasing demand for fish through aquaculture has expanded very rapidly and is now the fastest growing food-producing industry in the world. ${ }^{3}$ If the rapid growth of aquaculture persists, the feed requirement may increase many fold, hence for researchable ideas to sustain this is highly essential. Feeding of fish in aquaculture most especially in Nigeria has widely been reported as a renowned researchable aspect of aquaculture nutrition since it contributes about $60-70 \%$ of the total cost incurred during the fish production cycle as documented by Eyo, Abu et al. \& Sogbesan., ${ }^{2,45}$ The hike in price of fish feed is not limited to the cost and competitions for the ingredients used in formulation alone but also with the high cost of fish meal which is the most common source of animal protein. This fish meal contains high level of phosphorus far beyond the requirement for optimal growth in fish leading environmental pollution such as eutrophication. On the other side, Plant protein has been documented to have the potential of decreasing the problem of phosphorus pollution since plant does not contain high level of phosphorus ${ }^{6}$ hence, its use as feed ingredient can reduce the burden of fish meal. Soybean meal which has been coined a novel plant protein has attracted many industrial commercial importance leading to increase in its price and scarcity.

Cassava is a common name of starch production root crop Manihot esculenta because it is an important source of starch although the leaves which have been credited with major industrial and household usages are rich in protein (14-40\% dry matter), mineral, vitamin $B_{1}, B_{2}$, $\mathrm{C}$ and carotenes. Apart from lower methionine, lysine and isoleucine contents, the amino acid profile of cassava leaf protein compares favourably with those milk, cheese, soybean, fish and egg. ${ }^{7}$ The raw leaves of cassava plant can be toxic due to the natural nitrile compounds called cyanogenic glycosides or cyanogens, which are in the form of linamarin(93\%) and lotaustralin(7\%). They are $\beta$-glycosides of acetone cyanohydrins and ethyl-methyl cyanohydrins, respectively. Sarkiyayi \& Agar $^{8}$ reported that these precursors breakdown during fermentation to release the toxic compound hydrogen cyanide $(\mathrm{HCN})$; which is harmful to the consumers.

Oreochromis niloticus exhibit their best growth rates when fed a balanced diet that provides a proper mix of protein, carbohydrate, lipid, vitamins and minerals. Fry and fingerlings fish require a diet higher in protein, lipid, vitamins, minerals and lower in carbohydrates as they are need for developing of muscles, internal organs, bone and rapid growth while the adult needs more calories from fat and carbohydrate for metabolism and a smaller percentage of protein for growth. ${ }^{9,10}$ Thus this study is focused on the use of processed cassava leaf meal as partial replacer for soybean in the diet of Oreochromis niloticus fingerlings.

\section{Materials and Methods}

The research was conducted in the research farm of the Department of Fisheries, Modibbo Adama University of Technology (MAUTech), Yola. The University is located at Girei Local Government Area of Adamawa State. 


\section{Experimental materials}

100 Juveniles of Oreochromis niloticus with average weight $15.80 \pm 0.45 \mathrm{~g}$ and length, $8.50 \pm 0.12 \mathrm{~cm}$ were collected from the Research Farm of the Department of Fisheries, MAUTech, Yola. 6kg of fresh Cassava leaves (Manihot esculentus) were obtained from Cassava Farm in Ngurore, Yola South, Adamawa state. They were divided into two equal halves and each subjected to the different processing methods.

\section{Processing of the cassava leaves}

$3 \mathrm{~kg}$ were immersed in boiled water in a plastic container for

Table I Percentage composition of the experimental diets on dry matter basis

\begin{tabular}{llllll}
\hline Ingredients & $\mathbf{0}$ & $\mathbf{2 5} \%$ & $\mathbf{5 0 \%}$ & $\mathbf{7 5 \%}$ & $\mathbf{1 0 0 \%}$ \\
\hline Fish meal & 30.00 & 30.00 & 30.00 & 30.00 & 30.00 \\
Soybean meal & 32.50 & 24.38 & 16.25 & 8.13 & 0.00 \\
Fermented \& Sun-dried Cassava Leaf Meal & 0.00 & 8.13 & 16.25 & 24.38 & 32.50 \\
Rice bran & 15.00 & 15.00 & 15.00 & 15.00 & 15.00 \\
Maize meal & 15.00 & 15.00 & 15.00 & 15.00 & 15.00 \\
Starch & 2.00 & 2.00 & 2.00 & 2.00 & 2.00 \\
Palm oil & 1.50 & 1.50 & 1.50 & 1.50 & 1.50 \\
Vitamin Premixes & 1.50 & 1.50 & 1.50 & 1.50 & 1.50 \\
Calcium diphosphate & 1.00 & 1.00 & 1.00 & 1.00 & 1.00 \\
Methionine & 0.25 & 0.25 & 0.25 & 0.25 & 0.25 \\
Lysine & 0.25 & 0.25 & 0.25 & 0.25 & 0.25 \\
Salt & 1.00 & 1.00 & 1.00 & 1.00 & 1.00 \\
Total & 100.00 & 100.00 & 100.00 & 100.00 & 100.00 \\
Calculated Crude Protein & 35.00 & 35.00 & 35.00 & 35.00 & 35.00 \\
\hline
\end{tabular}

\section{Feeding experiment}

One hundred (100) Oreochromis niloticus fingerlings were allocated to 10 treatments at the rate of 8 fish per tank. The fish were fed at 5\% of their body weight twice daily from 8:00-9:00am and 4:00-5:00pm Madu \& Akilo. ${ }^{11}$ Uneaten feed and faecal matter were daily siphoned and dead fish were removed, counted and recorded.

An electronic weighing balance was used in determining the initial weight of each set of fish before stocking, later the weight was measured in batch weekly for each treatment throughout the period of the experiment. Also, a graduated meter rule was used in measuring the initial standard length of each set of fish before stocking, and weekly measurement followed throughout the feeding trial.

\section{Water quality analysis}

The physiochemical parameters were monitored throughout the feeding trials. Temperature was measured using mercury in-bulb thermometer, dissolved oxygen using Jenway DO Meter (9071), pH using pH meter (215) and Ammonia using Ammonia meter (96715).

\section{Proximate and hydocyanide analysis}

The fresh and differently processed cassava leaves were analysed for moisture, crude protein, fibre, ash, ether extract and nitrogen free extracts contents according to Association of Analytical Chemist Maduagwu. ${ }^{13}$

\section{Analysis of fish growth and nutrient utilization} ratio. $^{15}$

\section{Cost analyses} Ugwumba. ${ }^{16}$ These are: Fingerings Stocked (N)

$$
\text { Profit Index }=\frac{\text { Value of Fish }(\mathrm{N})}{\text { Cost of Feed }(\mathrm{N})}
$$

5mins. The container was covered for effective steaming and later, the leaves were filtered-out. $3 \mathrm{~kg}$ were soaked in a plastic rubber for five (5)days; and divided into two portions; the first portion was sun-dried while the second one was air-dried in the laboratory. The dried leaves were separately milled into powder, sieved and stored in polythene and labeled with the processing methods.

\section{Diet formulation}

Five $35.0 \%$ isocarloric diets were formulated and confirmed $40 \%$ of crude protein. The Fermented and Sun-dried Cassava Leaves Meal (FSCLM) was incorporate into each of these diets at $0 \%, 25 \%, 50 \%$ $75 \%$ and $100 \%$ to replace Soybean in the diets as shown in Table 1.

method $^{13}$ and Hydrocyanide following the method of Cooke \&

The growth was express as mean weight gain; specific growth rate, condition factor, and survival rate Fagbenro. ${ }^{14}$ Nutrient utilization indices were expressed as feed conversion ratio and protein efficiency

Cost evaluation of experiment diets was base on the current prices of the ingredients in the market. Cost of transportation of the cassava leaves from Ngurore, Yola South LGA, Adamawa State to Modibbo Adama University of Technology was recorded. The economic evaluations of the diets were calculated as outlined by Sogbesan \&

Estimated Investment Cost Analysis $=$ Cost of Feeding $(\mathrm{N})+$ Cost of 
Net Profit=Sales-Expenditure.

$$
\text { Benefit Cost Ratio }(\mathrm{BCR})=\frac{\text { Total Sales }}{\text { Total Expenditure }}
$$

\section{Statistical analysis}

Data were analysed using one-way analysis of variance (ANOVA) and where significant treatment differences were observe, treatment means were compared using Duncan New Multiple Range Test. The broken-line model of Robbins et al., ${ }^{17}$ was used to estimate the optimal fermented and sundried cassava meal inclusions based on the specific growth rate.

\section{Results}

\section{Proximate composition of different processed cassava leaves}

The proximate composition of the different processed cassava leave is given in Table 2. The fresh has the composition of $23.2 \%$ protein, $4.03 \%$ ether extra, $6.3 \%$ ash, $5.12 \%$ fibre, $58.1 \%$ moisture and $38.62 \%$ Nitrogen Free Extra; Blanched leave has $41.77 \%$ moisture, $25.8 \%$ protein, $4.21 \%$ ether extra, $6.1 \%$ ash, $2.55 \%$ crude fibre and $41.3 \%$ nitrogen free extra; Soaked and air-dried has $35.78 \%$ protein, $11.03 \%$ ether extra, $8.16 \%$ ash, $4.2 \%$ fibre, $6.35 \%$ moisture and $36.12 \%$ nitrogen free extra; Soaked and air-dried has $38.45 \%$ protein, $11.46 \%$ ether extract, $7.35 \%$ ash, $4.18 \%$ fibre, $5.88 \%$ moisture and $34.17 \%$ nitrogen free extract. Soaked and sun-dried ha the highest protein content of $38.45 \%$ while fresh has lowest content of $23.2 \%$. Crude fibre was highest in fresh and lowest in blanched with $2.55 \%$.
Ash content of $8.16 \%$ in soaked and air-dried is highest and $6.1 \%$ in blanched is lowest. Also the table shows that fresh cassava leaves has the cyanide content of $282 \mathrm{mg} / \mathrm{kg}, 105.03 \mathrm{mg} / \mathrm{kg}$ blanched leaves, $9.06 \mathrm{mg} / \mathrm{kg}$ soaked and air-dried leaves and $6.23 \mathrm{mg} / \mathrm{kg}$ soaked and sun-dried leaves. This shows a significant different $(\mathrm{p}>0.05)$

\section{Nutrient utilization of 0 . niloticus fed experimental diets}

The weekly percentage weight gain expressed on Figure 1 showed continuous growth for all the treatments. Table 3 shows a gradual increase in weight of fish fed the experimental diets. Fish fed $100 \%$ cassava leave meal diet inclusion had the highest mean weight gain (MWG) and mean length gain (MLG) with the values $18.83 \mathrm{~g}$ and $6.6 \mathrm{~cm}$ respectively and lowest in $50 \%$ cassava leave meal diet inclusion with values $5.67 \mathrm{~g}$ and $3.97 \mathrm{~cm}$ respectively. Highest specific growth rate (SGR) $(2.16 \%$ ) was recorded in fish fed $75 \%$ cassava leave meal diet inclusion and it is not significantly. The Robbin broken-line analysis shows that Mean weight gain $(\mathrm{g} / \mathrm{fish})=0.002 \mathrm{x}^{2}-0 \cdot 133 \mathrm{x}+8.416$; $\mathrm{R}^{2}=0.901$ with $Y \max =18.9 \mathrm{~g} /$ fish and $\mathrm{Xmax}=97.5 \%$ inclusion levels has shown in Figure 2. Table 4 showed highest significant correlation value $\mathrm{r}^{2}=0.99450,(\mathrm{p}<0.05)$ between the performances of $O$. niloticus fed $25 \%$ and $50 \%$ sundried and fermented cassava leaves meal diets. Table 5 shows a significant correlation between Mean weight gain (MWG) Percentage Weight gain (PWG) and Profit Index. The temperature ranged between $24.63-28.50^{\circ} \mathrm{C}$ during the experimental period and within the feeding trials. Similarly, Dissolved oxygen was between $6.20-8.30 \mathrm{mg} / \mathrm{L}, \mathrm{pH}$ between $6.90-7.80$ and ammonia was between $0.17-0.25 \mathrm{mg} / \mathrm{L}$.

Table 2 Proximate Composition and Cyanide Content of Different Processed Cassava Leaves

\begin{tabular}{lllll}
\hline Parameters & Fresh & Blanched & $\begin{array}{l}\text { Fermented+sun- } \\
\text { dried }\end{array}$ & $\begin{array}{l}\text { Fermented +air - } \\
\text { dried }\end{array}$ \\
\hline Moisture (\%) & $58.10^{\mathrm{a}}$ & $50.00^{\mathrm{a}}$ & $5.88^{\mathrm{b}}$ & $6.35^{\mathrm{b}}$ \\
Crude protein (\%) & $23.20^{\mathrm{b}}$ & $25.80^{\mathrm{b}}$ & $38.45^{\mathrm{a}}$ & $35.78^{\mathrm{a}}$ \\
Crude fibre (\%) & $5.12^{\mathrm{a}}$ & $2.55^{\mathrm{a}}$ & $4.18^{\mathrm{a}}$ & $4.20^{\mathrm{a}}$ \\
Ash (\%) & $6.30^{\mathrm{a}}$ & $6.10^{\mathrm{a}}$ & $7.46^{\mathrm{a}}$ & $8.16^{\mathrm{a}}$ \\
Ether Extract (\%) & $4.03^{\mathrm{b}}$ & $4.21^{\mathrm{b}}$ & $11.46^{\mathrm{a}}$ & $11.03^{\mathrm{a}}$ \\
Nitrogen free Extract (\%) & $38.62^{\mathrm{a}}$ & $41.30^{\mathrm{a}}$ & $34.17^{\mathrm{a}}$ & $36.12^{\mathrm{a}}$ \\
HCN(mg/kg) & $282.00^{\mathrm{a}}$ & $105.03^{\mathrm{b}}$ & $6.23^{\mathrm{c}}$ & $9.06^{\mathrm{c}}$ \\
Percentage HCN loss & 0.0 & 62.76 & 97.79 & 96.79
\end{tabular}

Mean of data on the same row with different superscripts are significant different $(p>0.05)$

Table 3 Growth, Feed Utilization and Cost Benefits of Oreochromis niloticus Fed Cassava Leaves Meal Diets

\begin{tabular}{llllll}
\hline Parameters & $\mathbf{0 \%}$ & $\mathbf{2 5 \%}$ & $\mathbf{5 0 \%}$ & $\mathbf{7 5 \%}$ & $100 \%$ \\
\hline Initial Mean Weight (g/fish) & $15.76^{\mathrm{a}}$ & $16.33^{\mathrm{b}}$ & $15.50^{\mathrm{a}}$ & $14.08^{\mathrm{c}}$ & $16.72^{\mathrm{b}}$ \\
Final Mean Weight (g/fish) & $24.3 \mathrm{I}^{\mathrm{b}}$ & $23.43^{\mathrm{b}}$ & $21.22^{\mathrm{b}}$ & $28.85^{\mathrm{a}}$ & $35.55^{\mathrm{c}}$ \\
Mean Weight Gain (g/fish) & $8.55^{\mathrm{b}}$ & $7.10^{\mathrm{b}}$ & $5.67^{\mathrm{b}}$ & $14.77^{\mathrm{a}}$ & $18.83^{\mathrm{a}}$ \\
Initial ML (cm) & $8.50^{\mathrm{a}}$ & $8.69^{\mathrm{b}}$ & $8.46^{\mathrm{a}}$ & $9.11^{\mathrm{b}}$ & $8.87^{\mathrm{a}}$ \\
Final Mean Length (cm) & $14.0 \mathrm{I}^{\mathrm{a}}$ & $14.69^{\mathrm{a}}$ & $12.43^{\mathrm{c}}$ & $13.39^{\mathrm{b}}$ & $15.47^{\mathrm{a}}$ \\
Mean Length Gain (cm) & $5.5 \mathrm{I}^{\mathrm{a}}$ & $6.00^{\mathrm{a}}$ & $3.97^{\mathrm{b}}$ & $4.28^{\mathrm{b}}$ & $6.60^{\mathrm{a}}$ \\
Specific Growth Rate (\%/day) & $2.06^{\mathrm{a}}$ & $1.79^{\mathrm{b}}$ & $1.88^{\mathrm{b}}$ & $2.16^{\mathrm{a}}$ & $1.75^{\mathrm{b}}$ \\
Feed Conversion Ratio & $1.67^{\mathrm{a}}$ & $1.69^{\mathrm{a}}$ & $1.46^{\mathrm{b}}$ & $1.72^{\mathrm{a}}$ & $1.66^{\mathrm{a}}$ \\
\hline
\end{tabular}




\begin{tabular}{llllll} 
Table Continued & & & & \\
\hline Parameters & $0 \%$ & $25 \%$ & $50 \%$ & $75 \%$ & $100 \%$ \\
\hline Percentage Weight Gain (\%) & $54.29^{\mathrm{b}}$ & $43.48^{\mathrm{bc}}$ & $36.46^{\mathrm{c}}$ & $104.90^{\mathrm{a}}$ & $112.62^{\mathrm{a}}$ \\
\hline Condition factor & $1.74^{\mathrm{a}}$ & $1.38^{\mathrm{b}}$ & $1.68^{\mathrm{a}}$ & $1.43^{\mathrm{b}}$ & $1.72^{\mathrm{a}}$ \\
Protein Efficiency Ratio & $1.23^{\mathrm{a}}$ & $1.10^{\mathrm{c}}$ & $1.27^{\mathrm{a}}$ & $1.31^{\mathrm{b}}$ & $1.3^{\mathrm{b}}$ \\
Survival rate (\%) & $68.75^{\mathrm{a}}$ & $50.00^{\mathrm{b}}$ & $62.50^{\mathrm{a}}$ & $37.50^{\mathrm{c}}$ & $37.50^{\mathrm{c}}$ \\
Profit Index & $1.11^{\mathrm{a}}$ & $1.06^{\mathrm{b}}$ & $1.06^{\mathrm{b}}$ & $1.29^{\mathrm{a}}$ & $1.49^{\mathrm{c}}$ \\
Incidence of cost & $121.64^{\mathrm{a}}$ & $139.43^{\mathrm{a}}$ & $165.78^{\mathrm{b}}$ & $60.26^{\mathrm{c}}$ & $44.61^{\mathrm{c}}$ \\
Cost Benefit Ratio(BCR) & $1.06^{\mathrm{a}}$ & $0.94^{\mathrm{b}}$ & $0.72^{\mathrm{b}}$ & $1.12^{\mathrm{c}}$ & $1.27^{\mathrm{c}}$ \\
Net Profit & $11.19^{\mathrm{a}}$ & $16.24^{\mathrm{b}}$ & $11.23^{\mathrm{a}}$ & $15.43^{\mathrm{c}}$ & $16.05^{\mathrm{b}}$ \\
\hline
\end{tabular}

Mean of data on the same row with different superscripts are significant different $(p>0.05)$

Table 4 Correlation $\left(r^{2}\right)$ of the treatments based on the determinant indices of Oreochromis niloticus fed fermented and sundried cassava leaves meal diets

\begin{tabular}{llllll}
\hline Treatments (diets) & $\mathbf{0 \%}$ (control & $\mathbf{2 5 \%}$ & $\mathbf{5 0 \%}$ & $\mathbf{7 5 \%}$ & $\mathbf{1 0 0 \%}$ \\
\hline $0 \%$ (Control) & & & & \\
$25 \%$ & 0.978097 & & & \\
$50 \%$ & 0.970301 & 0.994503 & & \\
$75 \%$ & 0.75164 & 0.675466 & 0.609511 & \\
$100 \%$ & 0.639602 & 0.545497 & 0.47101 & 0.984356
\end{tabular}

Table 5: Correlation $\left(r^{2}\right)$ of the indices based on the treatments of Oreochromis niloticus fed experimental diets

Keys: MLG - Mean length gain; SGR - Specific growth rate, FCR- Feed conversion ratio, PWG- Percentage

\begin{tabular}{|c|c|c|c|c|c|c|c|c|c|c|c|}
\hline $\begin{array}{l}\text { Indices } \\
\left(r^{2}\right)\end{array}$ & MWG & $M L G$ & $S G R$ & $F C R$ & PWG & $K$ & PER & $S R$ & PI & IC & $B C R$ \\
\hline MLG & 0.405606 & & & & & & & & & & \\
\hline SGR & -0.01229 & -0.59837 & & & & & & & & & \\
\hline FCR & 0.497682 & 0.486305 & 0.284489 & & & & & & & & \\
\hline PWG & $0.9830 \mathrm{I}$ & 0.26577 & 0.147092 & 0.534434 & & & & & & & \\
\hline $\mathrm{K}$ & 0.100922 & 0.126342 & -0.13092 & -0.45854 & 0.006159 & & & & & & \\
\hline PER & 0.627816 & -0.30688 & 0.331349 & -0.1586 & 0.665525 & 0.478097 & & & & & \\
\hline SR & -0.80742 & -0.25049 & 0.119418 & -0.4993 & -0.82704 & 0.44193 & -0.31984 & & & & \\
\hline $\mathrm{PI}$ & 0.986827 & 0.423586 & -0.12593 & 0.369729 & 0.948499 & 0.208047 & 0.65907 & -0.77028 & & & \\
\hline IC & $-0.98 \mid 14$ & -0.36875 & -0.1393 & -0.62981 & -0.98976 & 0.001226 & -0.58307 & 0.802732 & -0.9375 I & & \\
\hline$B C R$ & 0.897977 & 0.620623 & 0.064716 & 0.753344 & 0.870716 & 0.087017 & 0.365253 & -0.6277 & 0.850049 & -0.93022 & \\
\hline NP & 0.592937 & 0.505519 & -0.31775 & 0.637643 & 0.580378 & -0.6223 & -0.13921 & -0.88717 & 0.542788 & -0.60565 & 0.558576 \\
\hline
\end{tabular}

weight gain, K- condition factor, PER- Protein efficiency ratio, SR - Survival rate, PI - Profit Index, , IC- Incidence of cost, BCR - Benefit cost ratio 


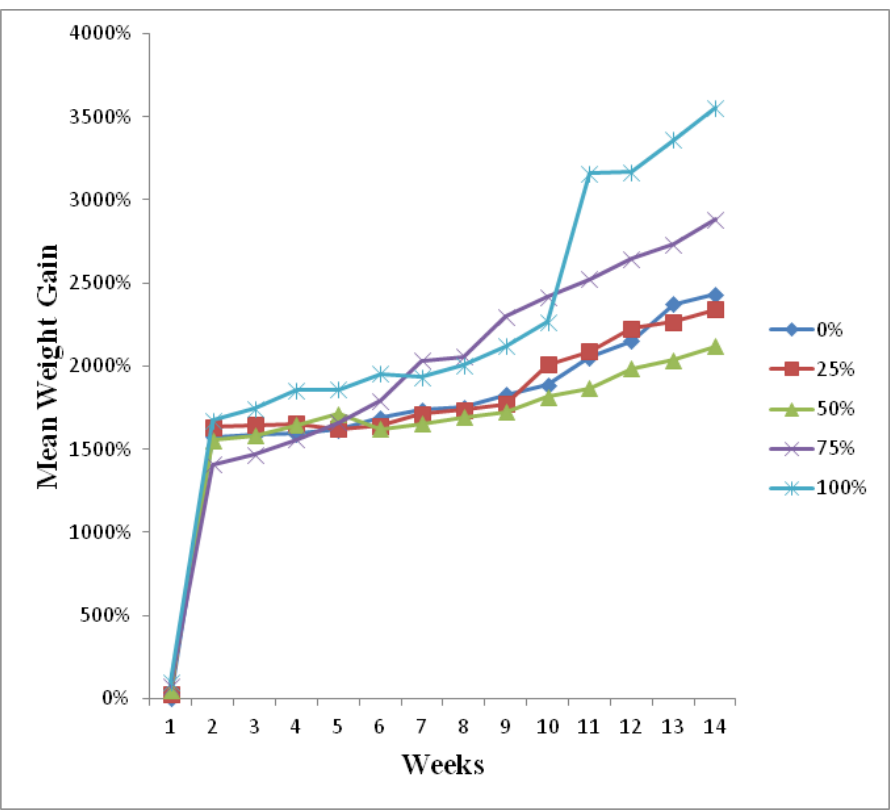

Figure I Weekly Percentage Weight Gain of Oreochromis niloticus fed Experimental diets for 84 days.

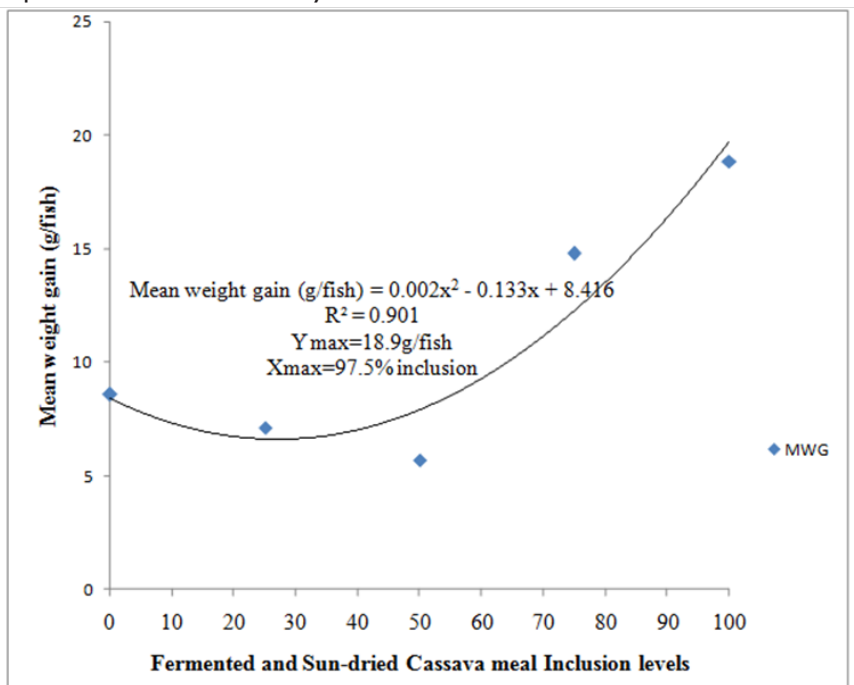

Figure 2 Broken-line analysis of the effect of Fermented and sun dried cassava meal diets on mean weight gain ( $g / f i s h)$ of Oreochromis niloticus.

\section{Discussion}

The physico-chemical parameters of the water for the experiment fall within the optimal ranges for optimum fish production. ${ }^{18}$ The chemical composition of Manihot esculenta leaf meal in this research collaborates with a prior finding of Fasuyi. ${ }^{7}$ However, values of chemical compositions were comparable with those reported in Moringa oleifera.$^{19}$ This shows that Manihot esculenta leaf meal has the potentials to supply some of the needed nutrients in aquaculture feed.

The cassava leaves processed through soaking and sun-drying had lowest HCN content of $7.42 \mathrm{mg} / \mathrm{kg}$. This collaborates with findings of Heuze \& $\operatorname{Tran}^{20}$ that sun-drying appears to be more efficient than oven drying $60^{\circ} \mathrm{C}$ for $\mathrm{HCN}$ reduction. $\mathrm{FAO}^{21}$ recommends $10 \mathrm{mg} / \mathrm{kg} \mathrm{HCN}$ body weight as the maximum safe intake of cyanide containing food/ feed for humans and animals.

Soaked and sun-dried cassava leaves were used at $0-100 \%$ in which the highest mean weight gain (MWG) of $18.83 \mathrm{~g}$ was in $100 \%$ cassava leave meal inclusion, while $8.55 \mathrm{~g}, 7.10 \mathrm{~g}, 5.67 \mathrm{~g}$ and $14.77 \mathrm{~g}$ are in $0 \%, 25 \%, 50 \%$ and $75 \%$ respectively. There is a significant difference $(p>0.05)$ in the parameters measured. This is in support with findings of Keong \& Leong ${ }^{22}$ that supplementation of $100 \%$ sun dried Cassava Leaf Meal protein diet with $0.1 \%$ methionine tended to improve growth performance in Oreochromis niloticus. Sun drying of whole cassava leaves of the sweet variety was effective in rendering the meal safe for incorporation in to pelleted diets. And also Heuze $\&$ Tran,${ }^{20}$ in which Fresh and sun dried cassava leaves from sweet variety were included at $76-83 \%$ in tilapia diets. Survival was $100 \%$ on all the diets and growth parameters were identical for fresh and dried cassava leaves, even though fresh leaves contained more HCN.

The increase in crude protein level from $23.20 \%$ in fresh to $35.78 \%$ in soaked and sundried is influenced by different processing techniques used in this study. This level of crude protein is also influenced by the fermentation process. Fermentation involves enrichment by direct and continues fermentation of products which are rich in starch and poor in protein. ${ }^{23}$ Cyanide levels are significantly different in leaves from different processing techniques. The study clearly shows that soaking and sun-drying is efficient processing method for the removal of HCN from cassava leaves.

All the experimental diets were accepted by the experimental fish indicating that the incorporation of soaked and sun dried cassava leaves meal diets did not adversely affect the palatability of the diets. The result was in comparable with Fagbenro ${ }^{14} \&$ Francis $^{24}$ who reported that reduction in anti-nutrients by different processing methods resulted in better palatability and growth in fish.

The protein efficiency ratio (PER) recorded for diet $100 \%$ cassava leaves meal inclusion was the highest (1.314) which indicates that Oreochromis niloticus fingerlings fed this diet utilize protein than fingerlings fed the other diets. Lowest Feed conversion ratio is an indication of the ability of fish to convert the feed and the nutrient into flesh for growth that any other feed as this was recorded in diets with cassava leaf meal compared to the control, meaning that clarias gariepinus were able to use the leaf protein better that the seed protein in the control. The condition factor $(\mathrm{K})$ were not significantly different $(\mathrm{p}>0.05)$ from all the treatment. Similar results were obtained by Thomas et al., ${ }^{25}$ and Bichi \& Ahmad. ${ }^{26,27}$

The profit index was higher in diet $100 \%$ cassava leaves inclusion than in all other experimental diets $0 \%, 25 \%, 50 \%$ and $75 \%$. This is an indication that replacement of soybean with cassava leaf meal can increase the profit benefit in feed production up to $97.5 \%$ inclusions according to Figure 2. Highest Benefit cost ratio and Net profit from $100 \%$ cassava leaves meal diet which is considered the best for Oreochromis niloticus. Despite this highest significant correlation $\left.\mathrm{r}^{2}=0.9844 ; \mathrm{p}<0.05\right)$ existed between all the indices used for fish performances in fish fed diets $75 \%$ and $100 \%$ putting these two diets as most appropriate for this research.

\section{Acknowledgements}

None. 


\section{Conflict of interest}

The author declares that there is no conflict of interest.

\section{References}

1. SOFIA. The State of World Fisheries and Aquaculture. 2014; 218 p.

2. Sogbesan OA. Non-conventional animal protein feedstuffs for the culture of catfish. Publisher Tetfund/ETF, Abuja, Nigeria. Published by Ibadan University Press. 2014; 109 p.

3. Tidwell JH, Allan GL. Fish as Food: Aquaculture Contribution Ecological and Economic Impacts and Contributions of Fish Farming and Capture Fisheries. EMBO Rep. 2001;2(11):958-963.

4. Eyo AA. Fish Processing Technology in the Tropics. National Institute for Fresh Water Fisheries Research, New Bussa, Niger State. 2003; p. 23-35.

5. Abu OMG, Sanni LO, Erondu ES. Economic Viability of Replacing Maize with Cassava Root Meal in the diet of Hybrid Cat-fish. Agricultural Journal. 2010; p 1-5

6. Sogbesan OA, Onoja CF, Adedeji HA, et al., Utilization of treated duckweed meal (Lemna pausicostata) as plant protein supplement in African mud catfish (Clarias gariepinus) juvenile diets. Fisheries and Aquaculture Journal. 2015; 6(3):141

7. Fasuyi AO. Nutrient Composition and Processing Effects on Cassava Leaf (Manihotesculenta, crantz) Antinutrients. Science Alert. 2005;4(1):37-42.

8. Sarkiyayi S, Agar TM. Comparative Analysis on the Nutritional and Anti-nutritional Contents of the Sweet and Bitter Cassava Varieties. Advance Journal of Food Science and Technology. 2010;2(6):328-334.

9. FAO. The State of World Aquaculture FAO Fisheries Technical paper. No. 500, Rome. 2006; 134 p.

10. FAO. Nile tilapia-Nutritional requirements. Aquaculture Feed and Fertilizer Resources Information System. 2015.

11. Madu CT, Aliko KT. The use of live maggot and life Tilapia fry as unconventional diets for Juveniles of the catfish (Clarias angullaris L). Fish nutrition and fish feed technology in Nigeria. In: Eyo AA ed processings of the first National symposium on fish Nutrition and fish Feed Technology (NIOMR) Lagos. 2001;72-80.

12. Association of Official Analytical Chemists. Official Methods of Analysis. 14th ed. Williams, editor. Arlington VAP. 2000; 102 p.

13. Cooke D, Marduagwu EN. The effect of Simple Processing on the cyanide content of cassava chips. Journal of Food Technology. 1985;(13):299-300.

14. Fagbenro OA. Comparative evaluation of heat processed winged bean (Psophocarpus tetragonolobus) meals as partial replacement for fishmeal in diets for African catfish (Clarias gariepenus). Aquaculture. 1999; 170(3-4):297-305.
15. Wilson RP. Amino Acids and proteins. In: JE Halver editor. Fish Nutrition. Academic Press Inc., California. 1989; p111-115.

16. Sogbesan OA, Ugwumba AAA. Bioeconomic evaluations of Garden Snail (Limicolaria aurora, Jay) Meat meal in the diet of Clarias gariepenus (Burchell, 1822) Fingerlings. Nigerian Journal of Fisheries. $2006 ; 2: 358-371$

17. Robbin KR, Norton HW, Barker DH. Estimation of nutrient requirements from growth data. J Nutr. 1979;109(10):1710-1714.

18. Anyanwu DC, Umeh OI, Ugo CK, et al., Nutrient Utilization and Growth of Catfish (Clarias gariepenus) Fed Dietary Levels of Cassava Leaf Meal. Pakistan Journal of Nutrition. 2012;11(11):1037-1040.

19. Dienye HE, Olumuji OK. Growth Performance and Haematological Responses of African mud catfish (clarias gariepenus) Fed Dietary Levels of Moringa oleifera Leaves Meal. Net Journal of Agriculture Science. 2014;2(2):79-88.

20. Heuze VA, Tran G. Cassava Leaves and Foliage. Feedipedia.org. A programme by INRA, CIRAD, AFZ and FAO. 2015.

21. FAO. Roots, tubers, plantain and bananas in human nutrition, Rome, 1990, Ch.7. Toxic substances and Anti-nutritional factor. 2011.

22. Keong WN, Leong KW. The Nutritive Value of Cassava Leaf Meal in Pelleted Feed of Nile tilapia. Journal of Aquaculture. 2015;83(1):45-58.

23. Ezeronye UA. Fermentation and protein enrichment of cassava peel and rumen digesta and their evaluation as diets in growing Swiss rat. Journal of Agricultural Biotechnology Environment. 2001;3(1):27-31.

24. Francis G, Makkar HPS, Becker K. Anti-nutrional factors present in plant-derived Putsztai. Biological effects of dietary lectins. In: alternative fish feed ingredients and their effects in Recent Advances of research in anti-nutritional fish. Aquaculture. 2001;199:197-227.

25. Thomas JS, Venu, Kuruo BM. Lenght-weight relationship of some deepsea fish inhabiting the continental slope beyond $250 \mathrm{~m}$ depth along the west-cost India. NAGA World Fish Center Quarterly. 2003;26:180-181.

26. Bichi AH, Ahmad MK. Growth performance and nutrient utilization of African catfish (Clarias gariepinus) Fed Varying Dietary levels of processed Cassava Leaves. Bayero Journal of Pure and Applied Science. 2010;3(1):118-122.

27. Boyd CE, Lichtkoppler F. Water Quality Management in Pond fish Culture research and Development series No. 22 international center for Aquaculture Agricultural experimental station, Aubum University, Alabama. 1979; 359 p. 